TEME, г. XLI, бр. 4, октобар - децембар 2017, стр. 1037-1053

\begin{tabular}{lr}
\hline \hline Оригинални научни рад & DOI: $10.22190 /$ TEME1704037M \\
Примљено: 27.9.2016. & UDK 371.3
\end{tabular}

UDK 371.3

Ревидирана верзија: 11. 9. 2017.

Одобрено за штампу: 15. 11. 2017.

\title{
ЕВАЛУАЦИЈА НИКОЛА ТЕСЛА ЦЕНТАР СИСТЕМА У І И V РАЗРЕДУ ОСНОВНЕ ШКОЛЕ
}

\author{
Александар Мратинковић, Марија Зотовић, \\ Марина Орос, Јована Трбојевић \\ Универзитет у Новом Саду, Филозофски факултет, \\ Одсек за психологију, Нови Сад, Србија \\ *aleksandar.mratinkovic3@gmail.com
}

\begin{abstract}
Апстракт
Циљ спроведеног истраживања било је вредновање Никола Тесла центар (у даљем тексту: НТЦ) система учења у школским условима и утврђивање његове евентуалне предности у односу на традиционалан облик наставе. Истраживање је обухватало два независна дела - тестирање ученика првог и петог разреда. Први узорак је сачињавало 46 ученика два одељења петог разреда, од којих је једно примењивало НТЦ систем учења, а друго традиционалан облик наставе. Ученици су тестирани Бондовим тестом логичких операција и упитником академске саморегулације. Постојање разлика у постигнућу је испитано ттестом. Статистички значајна разлика добијена је у постигнућу на Бондовом тесту логичких операција. Други узорак је чинио 31 ученик два одељења првог разреда, од којих је, као и у случају ученика петог разреда, једно примењивало НТЦ програм, а друго традиционалан облик наставе. Ученици су тестирани супскалама REVISK-a (речник, схватање и информације), скраћеном верзијом упитника академске саморегулације Бендер гешталт тестом и тестом дивергентног мишљења. Постојање разлика у постигнућу на наведеним тестовима је због малобројног узорка испитано непараметријским Mann-Whitney U тестом. Ни на једном тесту није забележено постојање статистички значајних разлика у постигнућу.
\end{abstract}

Кључне речи: НТЦ, рани основношколски узраст, BLOT, SRQ, REVISK.

\section{EVALUATION OF NIKOLA TESLA CENTER PROGRAM IN THE $1^{\text {st }}$ AND $5^{\text {th }}$ GRADE OF PRIMARY SCHOOL}

\footnotetext{
Abstract

The main aim of the conducted research was to evaluate the Nikola Tesla Center (hereandafter NTC) learning system in school settings and to assess its potential advantages over the traditional method of teaching. There were two samples in this research. The first sample consisted of 46 pupils from two classes of the fifth grade, from which one was using the NTC learning system, and the other one traditional
} 
forms of teaching. Pupils were tested with the Bond's logical operation test and academic self-regulation questionnaire. Differences between the two classes were tested using the t-test for independent samples. The results showed that fifth graders who were using the NTC learning system achieved a significantly higher score in the level of formal thinking development. The second sample consisted of 31 pupils from two classes of the first grade - one class was using the NTC system and the other one traditional method of teaching. First graders were tested with the REVISK subscales (vocabulary, understanding and information), short version of academic self-regulation questionnaire, Bender-Gestalt test and divergent thinking test. In this case, using the Mann-Whitney $U$ test (due to the small sample), no significant differences between these two groups were found on intelligence, motivation, visual-motor functioning and divergent thinking. Based on these results the effectiveness of the program in developing formal-operational thinking at age of 11/12 years can be assumed.

Key words: $\quad$ NTC, elementary school, BLOT, SRQ, REVISK.

\section{УВОД}

Школа има велику одговорност не само пред сваким појединачним дететом и његовом породицом већ и према целокупној друштвеној заједници (Bojanin, 1991). Имајући у виду значај и утицај ове институције, очигледна је потреба да се она у што већој мери учини ефективном, што би у овом случају подразумевало успешно подучавање, образовање и оспособљавање младих људи за будуће образовање и живот; задатак који додатно добија на значају имајући у виду брзину којом се данашње друштво мења, па самим тим и знања и компетенције потребне за успешно функционисање у њему.

Да ли школа остварује овај задатак? Велики број аутора сагласан је да је одговор на ово питање негативан (Dryden i Vos, 2001; Mejer, 2005; Maksić, 1995; Land \& Jarman, 1992; Simplicio, 2000).

Један од покушаја доприноса квалитету образовања је Никола Тесла центар (у даљем тексту НТЦ) програм (Rajović, 2011), тј. систем учења конципиран тако да превазиђе ограничења традиционалног облика наставе и утиче повољно на мотивацију ученика, њихово знање и мишљење. На тај начин се остварује одређена врста компромиса: наставни план и програм (тј. садржај) и даље је исти, једино је начин на који се он обрађује модификован, уз претпоставку да је поменута модификација у складу са интересовањима и карактеристикама узраста ученика.

\section{НТЦ СИСТЕМ}

НТЦ систем представља систем учења чији је циљ подстицање интелектуалног развоја деце предшколског и раног школског узраста (од 1. до 4. разреда) путем практичне примене сазнања из неурофизиологије (Rajović, 2009). Основан је 2001. године под називом „СИГ НТЦ” са сврхом пружања помоћи даровитим члановима Менсе 
(https://www.mensa.rs/sr/sigovi/NTC/), али убрзо мења име у „Одсек за даровите НТЦ”. Године 2008. спроведено је пилот-истраживање у предшколској установи „Радосно детињство” у Новом Саду, чији су резултати указали на то да активности НТЦ програма имају позитиван утицај на дечију радозналост, пажњу, мотивацију и концентрацију (Rajović i sar., 2009). У октобру исте године започета је и примена програма у оквиру наведене институције.

Након првих резултата програм је акредитован одлуком Завода за унапређење васпитања и образовања Републике Србије. Програм такође функционише и у Менси Србије, Матици српској, у Друштву учитеља Нови Сад, а део је плана и програма континуиране едукације Завода за унапређивање васпитања и образовања Републике Србије, који је намењен стручњацима из области образовања (http://www.mensa.rs/sr/sigovi/NTC/sistem-ucenja/). Поред тога, спроводи се у великом броју предшколских и школских установа у разним градовима Републике Србије, као и у 14 иностраних држава, од којих је у 6 акредитован.

\section{Неуролошка основа програма}

Податак да је програм заснован на сазнањима из области неурофизиологије нарочито је значајан имајући у виду да се државни програми за школе и предшколске установе углавном не заснивају на открићима из области неурофизиологије (Hannon, 2003). Познато је да процес мијелинизације, тј. мијелин, унапређује функционисање неурона тако што обавија његов аксон и на тај начин га изолује од осталих неурона, чинећи га проводљивијим (Hannaford, 2007). Улога мијелина је да обезбеди бржи пренос нервног импулса, што се постиже континуираним активирањем тог неурона и што за последицу има побољшање когнитивног функционисања (Posthuma, Michelle, 2003, према Bala i sar., 2013). Од пресудног значаја је податак да спољашњи стимулативни чиниоци доприносе процесу мијелинизације, тј. да је утврђена повезаност између стимулативних срединских фактора и процеса мијелинизације (Gojkov i sar., 2015). У складу са наведеним је Цецијев став да ће појединци, уколико им обезбедимо стимулативно и интересантно окружење, показати знатно виши ниво интелектуалног функционисања (Ceci, према: Gojkov i sar., 2015). Поред тога, сматра се да је развој интелектуалних способности повезан са бројем синапси (Diamond, 2001), за чије је стварање кључна двосмерна стимулација - од дендрита ка аксону и обрнуто, што се може обезбедити различитим видовима стимулације (Huttenlocher, 2002, према Pavlović, 2012).

Неуролози наглашавају значај ране стимулације услед синаптичке пролиферације које се одвија у том периоду; дакле, сматра се да постоји критичан период у развоју (Bruer, 1997). Ипак, други 
истраживачи радије бирају израз сензитиван период, јер термин критичан период сугерише да је учење онемогућено наког одређеног доба - међутим, иако је отежано, учење је и наког дотичног периода могуће (Goswami, 2004).

\section{Садржај НТЦ програма}

Програм се састоји из три фазе, од којих свака садржи карактеристичне вежбе и активности које нису обухваћене редовним наставним планом и програмом (Rajović, 2011). У циљу што бољег разумевања фаза и њихових специфичних активности, следи њихово кратко представљање и опис (треба поменути да се класификација која следи односи на прва четири разреда основне школе, иако постоје и активности које се примењују у предшколским установама):

1) Додатна стимулација развоја синапси - прва фаза подразумева редовне физичке вежбе које за циљ имају подстицање развоја синапси. Да би се обезбедила максимална ефикасност ових вежби, аутор у свом приручнику наводи низ методичких принципа којих се треба придржавати при извођењу вежби, као и сегменте на које је подељен сваки час (Rajović, 2011). Прва фаза програма обухвата следеће активности:

- Кинестезиолошке активности - садрже вежбе акомодације ока, равнотеже и ротације. Свака од наведених вежби важна је и претпоставља се да имају позитиван утицај на развој синапси.

- Графомоторичке вежбе - односно вежбе за развој фине моторике. Поред утицаја на синапсе, важне су и за вештину писања.

2) Стимулација развоја асоцијативног размишљања

- Технике меморије - садржи технику кратких филмова и технику дуплих асоцијација. Суштина је да се помоћу маштовитих и необичних асоцијација омогући памћење одређених појмова или њихово меморисање по одређеном редоследу.

- Мапе учења - заправо представљају мапе ума, које омогућавају визуелни приказ градива и његову хијерархијску организацију.

3) Функционално размишљање

- Загонетне приче - осмишљене су у циљу подстицања логичког размишљања и решавања проблема. У питању су приче које садрже интересантан проблем за који је потребно пронаћи решење, углавном путем креативног начина размишљања.

- Загонетна питања - кључно је да се до решења долази повезивањем познатих података и закључивањем новог. 
Раније евалуације НТЦ система учења

Осим личних запажања просветних радника о великом доприносу НТЦ програма у подстицању мотивације ђака и њиховом креативном и функционалном размишљању, постоје и истраживања која говоре у прилог његовој ефикасности. У једном таквом истраживању у ком је тестирана успешност НТЦ програма у раном музичком описмењавању, НТЦ систем учења показао се као успешнији од класичног методичког приступа (Šinić i sar., 2013). Исти аутори у свом раду указују на високу мотивисаност деце и чак на њихову одушевљеност НТЦ системом рада.

У оквиру другог истраживања (Nikolašević, Vujičić, 2010) дескриптивни подаци су указали на то да просветни радници који примењују НТЦ програм исти карактеришу као изузетно успешан и ефикасан. Тридесет три учитеља и наставника оценило је овај програм и чак $94 \%$ је задовољно његовим ефектима. Најбоље су оцењени следећи параметри: мотивација ученика за рад, трајност наученог, брзина усвајања наставног садржаја, радна атмосфера и укључивање креативности у наставни процес. Наставници и учитељи извештавају да је чак у $76 \%$ случајева постигнуће ученика побољшано након увођења НТЦ система, док $88 \%$ наставника и учитеља сматра да је након увођења програма било очигледно повећање мотивације ученика. Такође, $87 \%$ испитаних просветних радника сматра да је позитиван утицај на закључивање и брзину размишљања ученика последица примене програма.

Изучавајући ефекат НТЦ програма на дивергентну продукцију даровитих ученика, Гојков и сарадници (Gojkov i sar., 2015) указали су на то да ученици након десетодневне примене НТЦ програма постижу значајно боље резултате на тесту дивергентне продукције у односну на претест.

Једно од истраживања за предмет је имало питање утицаја прве две фазе програма на неуропсихолошки развој деце предшколског узраста (Telečki Krnjetin i sar., 2015). Деца две предшколске групе била су подељена у контролну групу, која је похађала стандардни план и програм, и експерименталну групу, чија је васпитачица, поред стандардног, последњих 9 месеци примењивала и НТЦ програм. Постојање ефекта програма тестирано је задацима из Пијажеове батерије за испитивање преоперационалног мишљења - конверзација количине, конверзација тежине, класификације и серијације. Статистички значајна разлика добијена је на тесту конзервације тежине и количине, у корист експерименталне групе. 


\section{МЕТОДОЛОГИЈА ИСТРАЖИВАҢА}

\section{Проблем и цииь истраживања}

Основни проблем истраживања представља евалуација НТЦ система, као и испитивање његових евентуалних предности у односу на традиционалан облик наставе, док би се циљ истраживања могао окарактерисати као покушај утврђивања ефикасности НТЦ програма посредством ученикових постигнућа на различитим тестовима, односно као одговор на питање да ли ће постојати разлике у постигнућу на тестовима између ученика који су похађали наставу по НТЦ програму и ученика који су похађали регуларну наставу.

\section{Хипотезе}

Имајући у виду досадашње резултате НТЦ програма, сведочанства која говоре у прилог његовој ефикасности, као и његову заснованост на неуролошким открићима, може се претпоставити да ће:

- ученици НТЦ групе петог разреда бити успешнији на Бондовом тесту логичких операција од одељења петог разреда које је похађало редовну наставу, као и да ће њихова мотивација у већој мери бити аутономно регулисана у односу на мотивацију ученика контролне групе;

- ученици НТЦ групе првог разреда бити значајно успешнији на суптестовима REVISK-a, тесту дивергентне продукције и Бендер гешталт тесту, као и да ће њихова мотивације у већој мери бити аутономно регулисана у односу на ученике првог разреда који су похађали редовну наставу.

\section{Узорак}

Истраживање је обухватало два независна узорка. Први су представљала два одељење петог разреда Основне школе „Вук Караџић” у Шапцу, подељена у НТЦ групу, у којој је било 24 ученика, и контролну, у којој их је било 22. Учитељица је ученицима НТЦ групе током прве четири године школовања наставно градиво представљала поштујући принципе НТЦ програма и поред тога свакодневно спроводила предложене физичке вежбе, док су ученици контролне групе похађали редовну наставу, предвиђену Наставним планом и програмом. Подаци са уписа у први разред указују на то да између две групе није постојала разлика у постигнућу на тесту интелигенције $(\mathrm{t}(54)=-0,844, \mathrm{p}>0,05)$, на тесту за испитивање првака ТИП $1(\mathrm{t}(54)=-0,882, \mathrm{p}>0,05)$, као ни на његовом подтесту логичке операције $(\mathrm{t}(54)=-0,974, \mathrm{p}>0,05)$.

Други узорак сачињавали су ученици два одељења првог разреда Основне школе „Вук Караџић”, тачније 31 ученик, од којих је 
$58,1 \%$ припадало експерименталној (разлог неуједначености броја испитаника је оправдано одсуство неколико ученика на дан тестирања). Експериментална група је од почетка школске године примењивала НТЦ програм (3 месеца), док је контролна спроводила традиционалан облик наставе. Између група није забележено постојање значајне разлике у постигнућу на тесту интелигенције при упису у први разред $(\mathrm{t}(32)=-0,581 ; \mathrm{p}>0,05)$.

\section{Проиедура}

Истраживање је спроведено унутар учионица Основне школе „Вук Караџић” у Шапцу. Ученици оба одељења петог разреда тестирани су истог дана, почетком септембра 2015. године. Сматрајући да ученици поседују способност за самостално решавање тестова, одлучено је да се спроведе групно тестирање; сваки тест је укратко представљен, након чега су ученицима подељени тестови. Оквирно време решавања било је 45 минута.

Ученици два одељења првог разреда тестирани су такође истог дана, крајем децембра 2015. године. Како су ученици тек започели своје школовање и још увек нису довољно овладали вештинама читања, писања и разумевања текста, мало је вероватно да би успели самостално решити тест, тако да је одлучено да се у њиховом случају спроведе индивидуално тестирање, које је спроведено анонимно и након сагласности родитеља у писаној форми.

\section{Инструменти}

Бондов тест логичких операција (BLOT - Bond's logical operations test; Bond, 1976) - за испитивање формалних операција коришћена је српска верзија Бондовог теста логичких операција (StepanovićIlić i sar., 2012). У питању је тест заснован на Пијажеовом концепту формалних операција (Inhelder \& Piaget, 1958), који обухвата свих 16 бинарних операција, формално-операционе шеме, као и трансформације у оквиру групе ИНРЦ (идентична трансформација, негација, реципрочна тренсформација, корелативна трансформација) и намењен је процени дечијег когнитивног развоја, односно утврђивању да ли дете користи логику на конкретном или формалном нивоу. У питању је тест вишеструког избора који се састоји од 35 ставки (тј. питања или задатака). Истраживања су показала да тест поседује задовољавајућу конструкт валидност и поузданост (Bond, 1995a), као и конкурентску валидност, демонстрирану поређењем BLOT-a са другим тестовима који такође испитују формалне операције (Bond, 1995a). Поред тога, добијена је тест-ретест поузданост од 0,91 за период дужи од 6 недеља (Bond, 1976). У истраживању које је спроведено Кронбахов алфа коефицијент износио је 0,64 . 
Упитник академске саморегулације (Academic Self-Regulation Questionnaire, SRQ-A; Ryan \& Connell, 1989) јесте упитник који произлази из Теорије самодетерминације. Упитник испитује мотивацију ученика за обављање школских задатака и састоји се од четири супскале које мере интринзичну мотивацију и три врсте екстринзичне (идентификовану, екстерну и интројектовану). Скала се састоји од 32 ставке које испитују мотиве због којих ученици обављају своје школске обавезе. Тачније, ученици су на питања „Зашто радим свој домаћи задатак?”, „Зашто радим задатке на часу?”, „Зашто покушавам да одговорим на тешка питања у школи?”, „Зашто покушавам (се трудим) да будем добар ученик?” одговарали тако што су изражавали степен сагласности са понућеним одговорима помоћу четворостепене скале Ликертовог типа (потпуно тачно, углавном тачно, углавном нетачно, потпуно нетачно) и на тај начин процењивали у којој је мери одређени мотив карактеристичан за њих. Наведене скале могу се интерпретирати појединачно, али се могу и комбиновати и на тај начин формирати индекс релативне аутономије (RAI $=2 \mathrm{x}$ интринзична + идентификована - интројектована - 2x екстерна), у оквиру ког су скале које представљају аутономни облик регулације пондерисане позитивно, за разлику од скала које представљају контролни облик регулације. RAI индекс указује на степен у ком је понашање самодетерминисано, односно аутономно регулисано.

Кранбахов алфа коефицијент за целокупну скалу износио је 0,90, док је поузданост за сваку од супскала представљена у Табели 1.

Табела 1. Поузданост скала упитника SRQ-A

\begin{tabular}{lc}
\hline Скала & $\alpha$-коефицијент \\
\hline Интринзична & 0,85 \\
Идентификована & 0,54 \\
Интројектована & 0,81 \\
Спољашња & 0,85 \\
\hline
\end{tabular}

За тестирање ученика првог разреда коришћена је краћа верзиja SRQ-A упитника, предвиђена за ученике са поремећајима у учењу (SRQ-A for students with LD; Deci i sar., 1992), чија је Кронбахова алфа износила 0,64. Разлог за коришћење наведене верзије упитника је претпоставка да би регуларан упитник првацима био превише сложен за разумевање. За разлику од оригиналне скале, која садржи 4 питања и више понуђених одговора за свако од њих, скраћена верзија садржи 16 засебних питања, на која се такође одговара путем четворостепене Ликертове скале (увек, углавном, понекад, никад).

REVISK (Biro, 1987) представља ревидирану верзију WISC Wechsler Intelligence Scale for Children (Wechsler, 1974); оригинална верзија упитника је преведена и адаптирана за наше подручје. Моди- 
фикација је успешно спроведена, тако да ревидирана верзија поседује задовољавајуће психометријске карактеристике. Међутим, у истраживању су коришћена само 3 суптеста (речник, информације и схватање) због њиховог предмета мерења, тј. чињенице да мере управо оне домене који би требало да одражавају ефекте НТЦ програма. Аутор ревидиране верзије скале у свом приручнику (Biro, 1988) наводи поузаност супскала изражених Кронбаховим $\alpha$-коефицијентом: Информације: 0,91; Схватање: 0,86; Речник: 0,89. У спроведеном истраживању поузданост суптестова је била нешто нижа и износила је: Информације: 0,70; Схватање: 0,61; Речник: 76.

Bender-Gestalt test (Bender, 1938) представља тест визуо-моторне перцепције и користи се у циљу одређивања степена графомоторног развоја и поред тога открива евентуалне неправилности у развоју визуо-моторне интеграције. Намењен је деци од 5 до 10 година. Састоји се од 9 цртежа, а задатак детета је да гледајући у цртеже исте прецрта на празан лист папира. Поузадност теста варира, па се тако поузданост процењивача креће од 0,80 до 0,96 (Tuševljak i sar., 1988.; Vormeland, 1968), док се тест-ретест поузданост креће од 0,50 до 0,90 (Tuševljak i sar., 1988).

Тест дивергентног мишљења представља задатак продукције што више речи на почетно слово $\boldsymbol{M}$. Време које су ученици имали на располагању за решавање овог задатка било је 2 минута.

\section{РЕЗУЛТАТИ}

У Табели 2 приказани су дескриптивни показатељи постигнућа ученика експерименталне и контролне групе петог разреда. Вредности Skewness-a i Kurtosis-a указују на то да дистрибуција не одступа значајно од нормалне.

Табела 2. Дескриптивни показатељи постигнућа ученика петог разреда

\begin{tabular}{lcccccc}
\hline \multirow{2}{*}{ Група } & N & $\begin{array}{c}\text { Просечан } \\
\text { резултат }\end{array}$ & дтандарднајација & Skewness & Kurtosis \\
\hline \multirow{2}{*}{ ВLOT } & НТЦ & 23 & 16,48 & 6,48 & 0,79 & \multirow{2}{*}{0,05} \\
& Контролна & 22 & 13,09 & 4,30 & & \\
\hline \multirow{2}{*}{ RAI } & НТЦ & 23 & $-13,56$ & 14,26 & 0,36 & \multirow{2}{*}{0,06} \\
& Контролна & 22 & $-13,36$ & 19,39 & & \\
\hline
\end{tabular}

Две групе ученика петог разреда постигле су значајно различите резултате на Бондовом тесту логичких операција $(\mathrm{t}(43)=2,05, \mathrm{p}$ $<0,05)$, док на упитнику академске саморегулације (односно RAI индексу) нису добијене значајне разлике $(\mathrm{t}(43)=0,97, \mathrm{p}>0,05)$. 
На основу увида у просечне резултате, јасно је да на BLOT-y разлика у постигнућу иде у корист НТЦ групе. Наведени разултати сугеришу да ученике који су припадали НТЦ групи у већој мери карактерише когнитивно функционисање типично за стадијум формалних операција.

Због малобројног узорка ученика првог разреда $(\mathrm{N}=31)$ paзлике су у овом случају тестиране непараметријским Mann-Whitney $\mathrm{U}$ тестом. Резултати су приказани у Табели 3.

Табела 3. Резултати Mann-Whitney U тестаразлике у постигнућу првака на тестовима

\begin{tabular}{|c|c|c|c|c|c|}
\hline & Група & $\begin{array}{c}\text { Просечан } \\
\text { резултат }\end{array}$ & $\begin{array}{c}\text { Mann- } \\
\text { Whitney U }\end{array}$ & $\mathrm{Z}$ & $\mathrm{p}$ \\
\hline Речник & $\begin{array}{c}\text { НТЦ } \\
\text { Контролна }\end{array}$ & $\begin{array}{l}15,44 \\
16,77\end{array}$ & 107,0 & $-0,402$ & 0,69 \\
\hline Информације & $\begin{array}{c}\text { НТЦ } \\
\text { Контролна }\end{array}$ & $\begin{array}{l}14,94 \\
17,46 \\
\end{array}$ & 98,0 & $-0,764$ & 0,45 \\
\hline Схватање & $\begin{array}{c}\text { НТЦ } \\
\text { Контролна }\end{array}$ & $\begin{array}{l}16,06 \\
15,92\end{array}$ & 116,0 & $-0,040$ & 0,97 \\
\hline $\begin{array}{l}\text { Дивергентно } \\
\text { мишљење }\end{array}$ & $\begin{array}{c}\text { НТЦ } \\
\text { Контролна }\end{array}$ & $\begin{array}{l}13,41 \\
18,23\end{array}$ & 75,0 & $-1,493$ & 0,13 \\
\hline RAI & $\begin{array}{c}\text { НТЦ } \\
\text { Контролна }\end{array}$ & $\begin{array}{l}16,69 \\
15,04\end{array}$ & 104,50 & $-0,501$ & 0,62 \\
\hline Графомоторика & $\begin{array}{c}\text { НТЦ } \\
\text { Контролна }\end{array}$ & $\begin{array}{l}15,75 \\
16,35\end{array}$ & 112,5 & $-0,181$ & 0.86 \\
\hline
\end{tabular}

Дакле, нису добијене значајне разлике у постигнућу ни на једном од тестова, док податак да су просечни резултати група готово једнаки (осим у случају Информација и Дивергентног мишљења) додатно илуструје непостојање разлика.

\section{ДИСКУСИЈА}

Циљ спроведеног истраживања био је допринос одговору на питање да ли НТЦ систем поседује одређене предности у односу на традиционалан облик наставе. Претпоставка је била да ће ученици петог и првог разреда основне школе који су наставу похађали у складу са НТЦ принципима бити успешнији на тестовима способности од својих вршњака који су похађали редовну наставу, као и да ће показати виши степен аутономне мотивације. Резултати истаживања указују на то да је претпоставка делимично потврђена.

Добијена је статистички значајна разлика у постигнућу на Бондовом тесту логичких операција између два одељења петог разреда, у корист групе која је наставу похађала у складу са НТЦ системом. Имајући у виду претежну уједначеност услова за оба одеље- 
ња, изводи се претпоставка да је НТЦ програм допринео овој разлици. То може указивати на то да НТЦ систем има улогу у поспешивању формално-операционалног мишљења на узрасту од 11-12 година, тј. на узрасту на ком се појављује могућност преласка са стадијума конкретних операција на стадијум формалних операција (Pijaže \& Inhelder, 1978; Pijaže, 1968). Ипак, није добијена разлика у степену аутономне мотивације, као ни на једној засебној супскали (интринзична, идентификована, екстернална и интројектована), иако аутор НТЦ програма као једну од његових најважнијих карактеристика наводи управо високу заинтересованост и мотивацију ученика за овај начин рада. Резултат је такође у супротности са теоријским претпоставкама неких аутора (Keller, 1979; Deci i sar., 1991) који сугеришу да ће ученици чија се настава организује на начин који им омогућава задовољење потреба за аутономијом и компетенцијом (што је у складу са НТЦ принципима) бити у већој мери интринзично мотивисани. Једна од околности која би делимично могла објаснити овакав резултат јесте могућност да ученици нису у потпуности разумели упитник академске саморегулације, односно формулацију питања. Чини се да је појединим ученицима било тешко да истовремено процесирају три засебна сегмента - само питање (Зашто радим свој домаћи задатак?), затим понућене одговоре (Зато што ћу се осећати лоше ако га не урадим; Зато што ћу имати невоље ако га не урадим...) и на крају процену колико је сваки од понуђених одговора близак са њиховом врстом мотивације за обављање одређене активности. Неки ученици су постављали питања у намери да схвате задатак, док је за неколицину њих било очигледно да не схватају инструкцију.

Поред тога, ипак треба узети у обзир и чињеницу да су, упркос НТЦ програму који има за циљ развој интринзичне мотивације, у школском контексту и даље присутни фактори који могу доприносити развоју екстринзичне мотивације - постигнуће ученика се вреднује, па делује да је коначан циљ добијање што боље оцене, тј. спољашње награде или признања. Чини се такође да је и сам начин примене НТЦ система важан фактор, тј. да активности програма саме по себи нису довољне да би довеле до очекиваних резултата. Ипак, како аутори нису имали увид у конкретан начин примене, његова анализа није могућа.

За разлику од ученика петог разреда, између два одељења првог разреда нису добијене разлике ни на једном од тестова (схватање, речник, информације, дивергентна продукција, Bender-Gestalt, упитник академске саморегулације). Делује да две околности у великој мери могу објаснити овакав резултат. Поред тога што два одељења првог разреда немају велики број ученика, на дан тестирања неколико њих није било присутно, тако да је укупан број испитаника био 31. Малобројност узорка представља један од потенцијалних фа- 
ктора који би, уколико би разлике постојале, могао неповољно утицати на њихово манифестовање. Такође, чињеница да је примена НТЦ система трајала три месеца (од почетка школске године) може бити значајна за разумевање одсуства разлика, јер постоји могућност да је тромесечни период једноставно прекратак да би активности НТЦ оствариле значајнији утицај.

Осим наведеног, у домену мотивације ученика оваквим резултатима вероватно је допринела и чињеница да су (као и у случају петог разреда) ученици првог разреда имали потешкоћа у разумевању упитника академске саморегулације, иако је у питању била скраћена, једноставнија верзија. За разлику од ученика петог разреда, у овом случају је било очигледно неразумевање упитника - ученици су збуњено давали одговоре, без озбиљнијег промишљања. Како је тестирање одмицало, поменуте околности биле су све упадљивије, тако да се у завршном делу јавила и незаинтересованост ученика, када се чинило да не посвећују пуну пажњу питањима. Дакле, делује да резултате упитника академске саморегулације не би требало сматрати потпуно поузданим.

На супскалама REVISK-a такође нису добијене разлике између два одељења првог разреда (речник, информације, схватање). Наведени суптестови REVISK-а коришћени су имајући у виду да су њихови предмети мерења способности које су блиске онима које би НТЦ програм требало да развија код ученика. Претпоставка је да кратак временски период примене НТЦ система учења није био довољан да би код ученика проузроковао претпостављени стимулативан утицај на когнитивно функционисање, мада је, као што је поменуто, евентуално постојање таквог утицаја могло остати незабележено због малобројног узорка.

Ha Bender-Gestalt тесту нису добијене значајне разлике у броју перцептивних и конструктивних грешака, што може сугерисати да НТЦ систем није значајно утицао на визуо-моторне способности првака.

Тест дивергентне продукције, као показатељ креативног потенцијала, заправо је представљао задатак продукције што више речи са почетним словом $\boldsymbol{M}$. Наведени тест је коришћен како би се стекао увид, и бар донекле обухватио креативан потенцијал ученика. Иако резултати нису у сагласности са прошлим истраживањем утицаја НТЦ програма на дивергентну продукцију, које је демонстрирало његов позитиван утицај (Gojkov i sar., 2015), ипак би требало нагласити да је у поменутом истраживању задатак дивергентне продукције био другачије природе, односно подразумевао је навођење што више употребних могућности различитих предмета, као и да су испитаници били даровити ученици. Поред тога, истраживање је било усредсређено искључиво на ову врсту способности (дивергентну продукцију). Постоји могућност да би се наведеним неповољним 
околностима (као у случају претходних тестова) могао делимично објаснити изостанак статистички значајне разлике између контролне и експерименталне групе на тесту дивергентне продукције.

Једна од предности истраживања у односу на остала која су се бавила овим проблемом је коришћење стандардизованих тестова са задовољавајућим психометријским карактеристикама (осим у случају теста дивергентне продукције, који би се могао окарактерисати као дескриптиван показатељ), што се може сматрати методолошким доприносом проучавању ефикасности НТЦ система у оквиру основношколске наставе.

Недостатак истраживања који би требало посебно нагласити тиче се структуре и величине узорка. Наиме, као резултат ограничавајућих околности, у истраживању је коришћен малобројан и небалансиран узорак. Имајући у виду значајност овог аспекта, у евентуалним будућим истраживања требало би обезбедити услове у којима ће бити могуће осигурати већи и боље избалансиран узорак.

Податак да ученици нису у потпуности схватили упитник академске саморегулације може послужити као користан податак за будућа истраживања - делује да би за ученике био адекватнији упитник који је формулисан на другачији, једноставнији начин, док је за прваке, чини се, одговарање путем скале Ликертовог типа неодговаpajyћe, јер већина њих још увек не поседује довољан капацитет и искуство за такав начин одговарања.

Било би пожељно у скоријој будућности поновити тестирање ученика и евентуално организовати лонгитудинално истраживање како би се на тај начин установило да ли ће се (и када) манифестовати ефекти НТЦ система код првака, те на тај начин стећи увид у потребан временски период примене програма пре него што се оствари његов утицај. Са друге стране, поновљена тестирања ученика петог разреда могла би одгонетнути питање дуготрајности ефеката НТЦ система учења.

Интересантно би било испитати да ли мотивација ученика има улогу модератор варијабле између активности НТЦ-а и постигнућа на тестовима способности или НТЦ систем доприноси повећању мотивације и способности ученика независно. Иако би се на основу резултата истраживања други случај могао учинити вероватнијим, то ипак није могуће претпоставити због поменутих отежавајућих околности.

\section{ЗАКљУЧАК}

Основни циљ спроведеног истраживања био је допринос одговору на питање да ли се НТЦ систем учења може сматрати ефикасним, односно да ли поседује одређене предности у односу на традиционалне наставне методе у домену мотивисаности ученика и њиховог когнитивног функционисања. 
Најважнији податак истраживања је да су ученици чија се настава спроводила у складу са НТЦ принципима постигли значајно боље резултате на Бондовом тесту логичких операција, што може сугерисати позитиван утицај НТЦ система у домену когнитивног функционисања ученика, конкретније на развој формално-операционалног мишљења на узрасту од 11 и 12 година.

Иако остале претпоставке о утицају НТЦ програма на мотивацију, дивергентно мишљење, графомоторику, као и постигнуће ученика на супскалама REVISK-a нису потврђене, било би неоправдано претпоставити неефикасност НТЦ система у развијању ових домена, имајући у виду наведене отежавајуће околности истраживања.

Иако је овом питању потребно посветити додатна истраживања како би се утврдило да ли се НТЦ систем може сматрати адекватном алтернативом традиционалном облику наставе, делује да резултати истраживања дају основу за претпоставку да би овај програм могао остварити ефекте у одређеним доменима као допунско наставно средство.

\section{ЛИТЕРАТУРА}

Bala, G., Drid, P. \& Madić, D. (2013) Neurofiziološka osnova motornog učenja i vežbanja kod dece [Neurophysiological basis of motor learning and exercise in children]. U G. Bala (Ur.) Mogućnosti poboljšanja kognitivnih, motoričkih i kardio-respiratornih sposobnosti dece pomoću kinezioloških aktivnosti (str. 135-165). Novi Sad: Fakultet sporta i fizičkog vaspitanja.

Bond, T. G. (1995a). Piaget and Measurement II: Empirical Validation of the Piagetian Model. Archives de Psyhologie, 63, 155-185.

Bond, T. G. (1976). BLOT: Bond's logical Operations Test. Townsville: TCAE.

Bojanin, S. (1991). Škola kao bolest [School as a disease]. Beograd: Biblioteka XX vek.

Biro, M. (1987). REVISK: Revidirana skala za merenje inteligencije po principima Wechslera [Revisk: The revised scale for measuring intelligence according to the principles Wechsler]. Beograd: Savez društava psihologa Srbije.

Biro, M. (1988). Priručnik za REVISK [REVISK manual]. Beograd: Zavod za udžbenike i nastavna sredstva.

Bender, L. (1938). A visual-motor Gestalt test and its clinical use. New York: American Orthopsychiatric Association.

Bruer, J. T. (1997). Education and the brain: A bridge too far. Educational researcher, 26(8), 4-16.

Deci, E. L., Hodges, R., Pierson, L., \& Tomassone, J. (1992). Autonomy and competence as motivational factors in students with learning disabilities and emotional handicaps. Journal of learning disabilities, 25(7), 457-471.

Deci, E. L., Vallerand, R. J., Pelletier, L. G., \& Ryan, R. M. (1991). Motivation and education: The self-determination perspective. Educational psychologist, 26(3-4), 325-346.

Diamond, M. C. (2001). Response of the brain to enrichment.Annals of the Brazilian Academy of Sciences, 73(2), 211-220. 
Dryden, G. i Vos, J. (2001.). Revolucija u učenju: kako promijeniti načina na koji svijet uci [A revolution in learning: how to change the way the world learns]. Zagreb: Educa.

Goswami, U. (2004). Neuroscience and education. British Journal of Educational Psychology, 74(1), 1-14.

Gojkov, G., Rajović, R., \& Stojanović, A. (2015). NTC learning system and divergent production. Istraživanja u pedagogiji, 5(1), 105-126.

Hannon, P. (2003). Developmental neuroscience: implications for early childhood intervention and education. Current Paediatrics, 13(1), 58-63.

Hannaford, C. (2007). Pametni pokreti [Smart moves]. Zagreb: Ostvarenje.

Inhelder, B., \& Piaget, J. (1958). The growth of logical thinking from childhood to adolescence. New York: Basic Books.

Keller, J. M. (1979). Motivation and instructional design: A theoretical perspective. Journal of Instructional Development, 2(4), 26-34.

Land, G., \& Jarman, B. (1992). Breakpoint and beyond: Mastering the future today. New York: Harper Business.

Maksić, S. (1995): Kreativnost kao cilj vaspitno-obrazovnog rada [Creativity as a goal of educational work]. Saznavanje i nastava, 151-170.

Meyer, H. (2005.). Što je dobra nastava? [What is good teaching?]. Zagreb: Erudita,

Nikolašević, Ž. i Vujičić, V. (2010.): Primena NTC - metoda učenja u praksi [Application of NTC - learning methods in practice], nepublikovan rad. Rad preuzet 15. aprila 2016. sa https://www.mensa.rs/resources/nikolasevic-zeljkavujicic-vesna-primena-ntc-ucenja-u-praksi.pdf

Pavlović, M. D. (2012). Neuropsihologija, bihevioralna neurologija i neuropsihijatrija [Neuropsychology, behavioral neurology and neuropsychiatry]. Beograd: Orionart.

Pavlović-Babić, D., Baucal, A., Kuzmanović, D. (2009). Naučna pismenost. PISA 2003 i PISA 2006 [Scientific literacy. PISA 2003 i PISA 2006]. Beograd: Ministarstvo prosvete Republike Srbije.

Pijaže, Ž. (1968). Psihologija inteligencije [Psychology of intelligence]. Beograd, Nolit.

Rajović, R. (2009). IQ deteta - briga roditelja, I deo: predškolski uzrast [IQ of the child-parents concern, Part I: preschool]. Novi Sad: Abeceda.

Rajović, R. (2011). Kako uspešno razvijati IQ deteta kroz igru. II deo: Uzrast od 4 do 8 godina [How to successfully develop a child's IQthrough play. Part II: From 4 to 8 years]. Novi Sad: Smart production.

Rajović, R., Dautović, S., Andre, L. (2009). NEUROFIZIOLOGIJA - primena novih otkrića u formiranju intelektualne elite: Primena programa NTC SISTEM UČENJA u razvoju intelektualnih sposobnosti dece [NEUROPHYSIOLOGY - the application of new discoveries in forming the intellectual elite: Use of the NTC LEARNING SYSTEM in the development of intellectual abilities of children]. Daroviti i društvena elita, 15, 510-518.

Ryan, R. M., \& Connell, J. P. (1989). Perceived locus of causality and internalization. Journal of Personality and Social Psychology, 57, 749-761.

Stepanović-Ilić, I., Baucal, A., \& Bond, T. G. (2012). Parallel Serbian versions of blot test: An empirical examination. Psihologija, 45(2), 121-137.

Simplicio, J. S. (2000). Teaching classroom educators how to be more effective and creative teachers. Education, 120(4), 675-680.

Tuševljak, M., Bele-Potočnik, Ž., Bras, S. (1988), Bender likovni test - razvojni sistem ocjenjivanja (priručnik) [Bender visual test - developmental appraisal system (manual)]. Ljubljana: Zavod SR Slovenije za produktivnost dela.

Vormeland, O. (1968), The Bender Gestalt Test as a group test with young school children, Scandinavian Journal of Educational Research, 12(1), 21-38. 
Vallerand, R. J., \& Fortier, M. S. (1998). Measures of intrinsic and extrinsic motivation in sport and physical activity: A review and critique. Advances in sport and exercise psychology measurement, 81-101.

Wechsler, D. (1974). Manual for the Wechsler intelligence scale for children-revised. New York: Psychological Corporation.

Šindić, A, Rajović, R., Suzić, N. (2013) Primjena NTC sistema učenja u početnom muzičkom opismenjavanju [Application of NTC system of learning in the initial musical literacy]. Naučni skup „Metodološki problemi istraživanja darovitosti” (str. 366-381). ISBN 978-86-7372-171-2.

\section{EVALUATION OF NIKOLA TESLA CENTER PROGRAM IN THE $1^{\text {st }}$ AND $5^{\text {th }}$ GRADE OF PRIMARY SCHOOL}

Aleksandar Mratinković, Marija Zotović, Marina Oros, Jovana Trbojević

University of Novi Sad, Faculty of Philosophy, Department of Psychology, Novi Sad, Serbia

\section{Summary}

One of the most important tasks for thesociety is education and preparation of youth for successful functioning in society. Considering the speed in which today's society is changing it is particularly important to develop functional knowledge, in order to allow the application of the acquired knowledge in different circumstances.

A large number of authors agree that the school system has proved unsuccessful in developing this kind of knowledge and skills. The NTC program is a learning system that aims at developing the intellectual abilities of children and their functional knowledge through a practical application of neurophysiology findings. Through various methods and techniques, pupils are enabled to learn in a way that they find interesting.

In the present study the convenience sampling method was used. Four classes were tested, two from the first and two from the fifth grade. In both cases (the first and the fifth grade) one class was studying according to the NTC program and the other one according to the traditional forms of teaching. There were 31 pupils in the first grade, of which $58.1 \%$ belonged to the NTC class, and $41.9 \%$ to the traditional class (control group). There were no significant differences between the two classes in gender $\left(\chi^{2}(1, \mathrm{n}=31)=\right.$ $0.45, \mathrm{p}=.833)$, number of pupils engaged in extracurricular sports activities $\left(\chi^{2}(1, \mathrm{~N}=\right.$ $31)=0.87, \mathrm{p}=.768)$, number of pupils attending a language school $\left(\chi^{2}(1, \mathrm{~N}=31)=\right.$ $0.39, \mathrm{p}=.844)$, and in the achievement on the intelligence test when enrolling in first grade $(\mathrm{t}(32)=-0.581, \mathrm{p}>.05)$. There were 46 pupils in the fifth grade $(52.1 \%$ NTC class, $47.9 \%$ control group). Between these two classes there were no significant differences in gender $\left(\chi^{2}(1, \mathrm{~N}=46)=0.538, \mathrm{p}=.463\right)$, number of pupils engaged in extracurricular sports activities $(\chi 2(1, \mathrm{~N}=46)=0.184, \mathrm{p}=.668)$, or in the number of pupils attending a language school $(\chi 2(1, \mathrm{~N}=46)=0.407, \mathrm{p}=.524)$.

For the first grade instrument the REVISK subscales (vocabulary, understanding and information) (Biro, 1987), short version of academic self-regulation questionnaire (SRQA for students with LD; Deci et al., 1992), Bender-Gestalt test (Bender, 1938) and divergent thinking test. For the fifth grade instruments used were Bond's logical operation test (Bond, 1976) and academic self-regulation questionnaire (Ryan \& Connell, 1989 were used). 
Between the two classes of the first grade there were no statistically significant differences in intelligence, motivation, visual-motor functioning and divergent thinking. Between the two classes of the fifth grade there was a statistically significant difference in the level of formal thinking development. Based on these results, it can be suggested that the NTC program has demonstrated its influence on developing formal-operational thinking at age of $11 / 12$ years.

Even though the absence of significant difference on academic self-regulation questionnaire seems surprising, these results could be partially explained by the pupil's insufficient understanding of the questionnaire. The absence of a significant difference between the two classes of first graders on the short version of academic self-regulation questionnaire could be explained by several factors. First, it was obvious that they couldn't understand the questionnaire completely. Second, the fact that a school system still encourages extrinsic motivation (regardless of the NTC program) can also be one of the causes. Also, a potential effect could have been unrecorded due to the small sample size. And finally, maybe a three month period is not enough for the NTC program to display its effects.

It seems that the conducted research has methodological contribution to examination of the NTC program efficiency in school setting, considering the use of standardized tests with satisfactory psychometric properties.

The future research should use motivation questionnaires that have simpler formulation. Besides the already mentioned, future research should include longitudinal design in order to answer whether the NTC system has long lasting effects, and also to establish what is the required period for the NTC system to display its effects. 